\title{
Editorial
}

\section{The Glucagon-Like Polypeptides - Order out of Chaos?}

\author{
J. M. Conlon \\ Department of Clinical Biochemistry, Royal Victoria Infirmary, Newcastle upon Tyne, England
}

The demonstration that extracts of gastrointestinal tissue [1] and blood [2] are associated with a glucagon-like ability to activate hepatic adenylate cyclase and to promote hyperglycaemia predates the radioimmunoassay era. The main upsurge in interest in substances related to glucagon is, however, a consequence of the development of routine radioimmunoassays for the hormone [3]. It has become apparent, as more laboratories engage in studies, that there is a lack of commonly accepted terminology to describe the glucagon-like polypeptides. Confusion regarding their relationship to glucagon has meant that much of the published work relating to these substances is unintelligible to the general scientific reader and not infrequently to other specialists in the field. In this article, it is proposed to give a brief account of the physicochemical and biological properties of the glucagon-like polypeptides in tissues and plasma, to assess their importance in physiology and to examine their structural and biosynthetic relationship to glucagon. In the course of this, a standard nomenclature will be proposed.

As radioimmunoassays for glucagon became more sophisticated [4], it became apparent that the immunoreactive material present in extracts of mammalian gut and released by the gut in response to a glucose load was immunochemically distinct from glucagon. One group of antibodies raised against glucagon reacted strongly with materials of enteric and pancreatic origin but a second group of antibodies reacted only very weakly with material from the gut. Initially, the former group of antibodies were described as "cross-reactive" or "non-specific" and the latter group as "pancreatic glucagon specific" but, following the work of Senyk et al. [5], Assan and Slusher [6] showed that "non-specific" antibodies were directed against an immunodeterminant in the amino-terminal and central portion of the glucagon molecule (amino acid residues [2-23]). The immunodeterminant for "specific" antibodies was located towards carboxyl-terminal region of the molecule (residues [24-29]). The terms " $\mathrm{N}$-terminal specific" and "C-terminal specific", applied to antiglucagon sera, have now superceded the original classification. In this light, an empirical terminology to describe the glucagon-like polypeptides has been proposed by the nomenclature committee of the International Glucagon Symposium, Dallas, USA (1976) [7] but, regretably, the recommendations of the committee have not been universally adopted. It was proposed that the glucagon-like polypeptides are to be classified on the basis of their reactivity towards antibodies of known regional specificity. Irrespective of their tissue of origin, polypeptides which react with both $\mathrm{C}$ - and $\mathrm{N}$-terminal specific antibodies are termed "Immunoreactive glucagon, IRG" and polypeptides which react only with $\mathrm{N}$-terminal specific antibodies are termed "Glucagon-like immunoreactitity, GLI". The approximate molecular weight of a component is given as a superscript, e. g. IRG ${ }^{3500}$.

The glucagon-like polypeptides in tissue extracts and plasma can be separated on the basis of molecular size and charge into multiple molecular forms. In addition to glucagon, pancreatic tissue extracts contain an acidic $(\mathrm{pI}=4.7) \mathrm{IRG}$ component of approximate molecular weight of 9000 , together with immunoreactive materials of smaller molecular size than glucagon which may represent degradation products [8]. A similar distribution of molecular forms is found in extracts of canine stomach [8] but evidence for the existence of appreciable quantities of gastric glucagon-like material in man is lacking. GLI components with approximate molecular weights of 12000 and 8000 and with isoelectric points in the range 6-8 represent the predominant immunoreactive forms in gut extracts $[9,10]$, but a smaller $(M W \approx 4500)$, 
basic ( $\mathrm{pI} \geqslant 9.5$ ) GLI in the gut has also been identified by a number of workers $[11,12]$. It is an oversimplification, however, to identify IRG exclusively with the pancreas and GLI exclusively with the gut. The presence of GLI components in the pancreas [13] and IRG components in the gut [14] has been demonstrated both by radioimmunoassay and immunohistochemical techniques. Glucagon-like polypeptides have recently been detected in the central nervous system of the dog [15] and rat [16] and are found in high concentrations in the salivary glands of rodents [17]. The IRG ${ }^{9000}[8], \mathrm{GLI}^{12000}$ [9] and $\mathrm{GLI}^{8000}$ [9] components are probably devoid of glucagon-like biological effects on metabolism but the $\mathrm{GLI}^{4500}$ component has been shown to bind to receptor sites specific for glucagon in hepatic plasma membranes [11], to activate hepatic adenylate cyclase [11] and to stimulate glycogenolysis [12], although with a potency less than that of glucagon.

Considerable problems are associated with the measurement and characterisation of the glucagonlike polypeptides in plasma. IRG components of approximate molecular weight 9000,3500 and 2000 , corresponding to the forms in tissue extracts, also circulate in plasma [18] but immunoreactivity, which can comprise up to $100 \%$ of the total, is also detected in the gamma-globulin $(\mathrm{MW} \approx 160000)$ fraction of plasma [19]. This poorly characterised component was initially described as an "interference factor" in radioimmunoassays [20] but is now generally referred to as "Big Plasma Glucagon, BPG". In the absence of conclusive experimental evidence, it has been proposed that BPG represents 1) a biosynthetic precursor of glucagon which is released into the circulation 2) a component which possesses sufficient homology with glucagon to be able to interfere specifically in radioimmunoassays by competing for antibody binding sites, 3 ) a component which interferes non-specifically in radioimmunoassays by interacting with antibody thereby blocking binding sites, 4) an artifact arising from degradation of the radiolabelled tracer and 5) glucagon or degradation products of glucagon bound to plasma components. At the present time there is no indication that BPG is important in metabolism.

The presence of GLI in blood was first suggested by Samols et al. [4] but the molecular forms of the circulating GLI components have not been adequately characterised. Plasma GLI concentrations are routinely determined by subtracting the level of immunoreactivity measured with a C-terminal specific antiserum from the level measured with an $\mathrm{N}$-terminal specific antiserum. The precise significance of this difference in molecular terms is unclear. In view of the marked physicochemical and biological heterogeneity of the IRG and GLI components, it is difficult to correlate changes in the levels of plasma immunoreactivity with physiological events. Similarly, the rapid proteolytic degradation of the glucagon-like polypeptides in plasma results in the circulation of multiple immunoreactive, but biologically inactive, $\mathrm{C}$ - and $\mathrm{N}$-terminal fragments of glucagon so that the assumption that an $\mathrm{N}$-terminal specific antiserum measures total immunoreactivity is inaccurate. It follows that terms such as the "enteroglucagon" response to a particular stimulus can be misleading unless it is made clear, in molecular terms, exactly what has been measured in the assays.

At the present time, there is insufficient evidence to assign a biological role to the glucagon-like polypeptides. Although hypotheses have been presented linking gut GLI with enterogastrone activity [21], inhibition of gastrointestinal motility [22], a trophic effect upon gut mucosa [22], anti-lipolytic activity [23] and inhibitory effects upon glucagon-induced glycogenolysis [24] and insulin-induced hepatic glucose uptake [25], conclusive evidence in support of these hypotheses is required. Indeed, it has been suggested [26] that the gut GLIs may simply represent a primitive peptide family from which the structurally related and biological active hormones glucagon, secretin, VIP and GIP may have evolved but that specialised biological activity is manifested only by the descendant polypeptides. Nevertheless, firm evidence linking the $\mathrm{GLI}^{4500}$ component from the gut with glucagon-like biological activity has been provided and this component may play a role in carbohydrate metabolism. Pancreatectomised man has been proposed as a model for diabetes without glucagon [27] but it has been pointed out [28] that the GLI ${ }^{4500}$ component, undetectable with C-terminal specific antibodies, probably circulates in pancreatectomised man and may be important in promoting hyperglycaemia. Consequently, the assertion that insulin-lack is the only factor responsible for the abnormalities of carbohydrate metabolism in these subjects requires further examination.

In recent years, a number of studies have provided firm evidence that all the glucagon-like polypeptides of the pancreas and gut share a common biosynthetic pathway and may be derived from a common precursor molecule. A 100 amino acid polypeptide, glicentin, has been isolated from porcine gut and shown to contain the full sequence of glucagon, extended from the $\mathrm{N}$-terminus by 63 amino acids and from the C-terminus by a basic 8 amino acid chain $[29,30]$. A basic 4500 dalton GLI component, isolated from bovine/porcine pancreas was similarly shown to contain the full sequence of glucagon extended from the C-terminus by the same 8 amino 


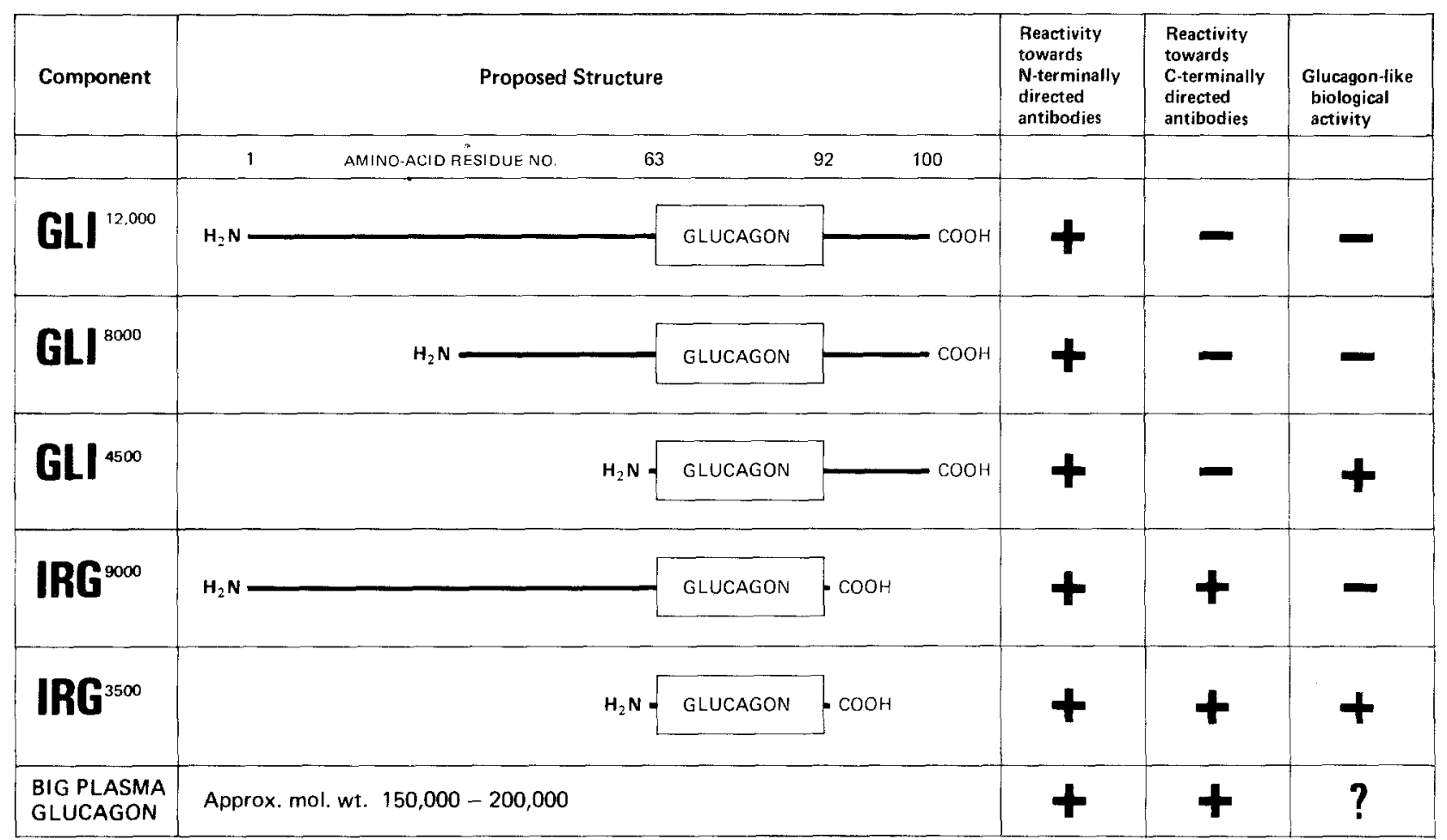

Fig. 1. Predominant molecular forms of the glucagon-like polypeptides

acids [31]. Furthermore, immunofluorescence studies, using an antiserum raised against glicentin that does not bind glucagon, have shown the presence of the glicentin immunodeterminant in the A cells of the pancreas [32] and stomach [33] as well as in the $\mathrm{L}$ cells of the gut $[32,33]$.

These and related studies [10] have provided evidence for the proposed structures of the predominant molecular forms of the glucagon-like polypeptides which are shown in Figure 1. IRG components represent the full sequence of glucagon extended from the $\mathrm{N}$-terminus only so that the C-terminal immunodeterminant of glucagon is accessible to antibodies. GLI components also contain the full sequence of glucagon but are extended from the Cterminus as well so that the C-terminal immunodeterminant of glucagon is now inaccessible to antibodies. Progressive shortening of the N-terminal extension to the glucagon sequence in the common precursor of the glucagon-like polypeptides, without removal of the $\mathrm{C}$-terminal extension, gives rise to the GLI components which predominate in the intestine. In contrast, removal of the C-terminal extension to the glucagon sequence, at some stage in the biosynthetic pathway, gives rise to the series of IRG components which predominate in the pancreas. It can be seen from Figure 1 that glucagon-like biological activity is manifested only by those polypeptides that lack an $\mathrm{N}$-terminal extension to the glucagon sequence. Conflicting reports from a number of laboratories, involving incorporation of radiolabelled amino acids into islet tissue from a variety of species, have suggested a molecular weight of between 12000 and 69000 for the biosynthetic precursor. In a recent study [34], analysis of newly synthesis proteins from rat islets has identified an 18,000 dalton polypeptide as proglucagon which was converted, under pulsechase conditions into immunoreactive polypeptides with molecular weights of 13000,4500 and 3500 .

The concept that post-translational modifications of a single primary gene product can generate a family of structurally related polypeptides is well established in endocrinology. For example, the lipotropins, endorphins, melanotropins, corticotrophin and met-enkephalin probably derive from a single 31000 dalton precursor, pro-opiocortin [35]. It is clear, therefore, that the different distribution of the glucagon-like polypeptides in tissues is not due to a difference in the primary gene product of the endocrine cells in those tissues. It is a consequence of the different processing of a single product by proteolytic enzymes in the cells.

The author hopes that this article has gone some way in removing the study of the glucagon-like polypeptide from the realm of esoteric lore and placing it in the mainstream of polypeptide endocrinology. It is 
not suggested that the terminology used in this article represents the "final" classification. Nevertheless, workers are urged to compromise their rigidly held views regarding nomenclature in order to achieve a greater measure of linguistic uniformity from which a clearer understanding may develop.

\section{References}

1. Sutherland E W, de Duve C (1948) Origin and distribution of the hyperglycemic-glycogenolytic factor of the pancreas. J Biol Chem 175: 663-674

2. Makman MH, Makman RS, Sutherland EW (1958) Presence of a glucagon-like material in blood of man and dog. J Biol Chem 233: 894-899

3. Unger RH, Eisentraut A M, McCall MS, Madison L L (1961) Glucagon antibodies and an immunoassay for glucagon. J Clin Invest 40: 1280-1289

4. Samols E, Tyler J, Megyesi C, Marks V (1966) Immunochemical glucagon in human pancreas, gut and plasma. Lancet II: $727-729$

5. Senyk G, Nitecki DE, Spitler L, Goodman JW (1972) The immune respone to glucagon in conjugated form. Immunochemistry 9: 97-110

6. Assan R, Slusher N (1972) Structure/function and structure/ immunoreactivity relationships of the glucagon molecule and related synthetic peptides. Diabetes 21: 843-855

7. Unger RH (1976) Glucagon Symposium: Report of the Nomenclature Committee. Metabolism 25 [Suppl 1]: ix

8. Srikant CB, McCorkle K, Unger RH (1977) Properties of immunoreactive glucagon fractions of canine stomach and pancreas. J Biol Chem 252: 1847-1851

9. Conlon J M, Murphy RF, Buchanan KD (1979) Physicochemical and biological properties of glucagon-like polypeptides from porcine colon. Biochim Biophys Acta 577, 229-240

10. Tager HS, Markese J (1979) Intestinal and pancreatic glucagon like polypeptides. J Biol Chem 254, 2229-2233

11. Bataille D, Freychet P, Rosselin G (1974) Interactions of glucagon, gut glucagon, vasoactive intestinal polypeptide and secretin with liver and fat cell membranes: Binding to specific sites and stimulation of adenylate cyclase. Endocrinology 95: 713-721

12. Holst J J (1977) The interactions of the glucagon receptor of liver cell membranes with pancreatic and gut type glucagon. In: Foa PP, Bajaj JS, Foa NL (eds) Glucagon, its role in physiology and clinical medicine. Springer, Berlin Heidelberg New York, p 287-303

13. Srikant CB, Unger RH (1976) Evidence for the presence of glucagon-like immunoreactivity (GLI) in the pancreas. Endocrinology 99: 1655-1658

14. Larsson L-I, Holst J, Hakanson R, Sundler F (1975) Distribution and properties of glucagon immunoreactivity in the digestive tract of various mammals: An immunohistochemical and immunochemical study. Histochemistry 44: 281-290

15. Conlon JM, Sampson WK, Dobbs RE, Orci L, Unger RH (1979) Glucagon-like polypeptides in canine brain. Diabetes 28: 700-702

16. Loren I, Alumets J, Hakanson R, Sundler F, Thorell J (1979) Gut-type glucagon immunoactivity in nerves of the rat brain. Histochemistry 61: 335-341

17. Lawrence AM, Tan S, Hojvat TS, Kirsteins L (1977) Salivary gland hyperglycemic factor. An extrapancreatic source of glucagon-like material. Science 195: 70-72

18. Kuku SF, Zeidler A, Emmanuel D S, Katz Al, Rubenstein A H, Levin NW, Tello A (1976) Heterogeneity of plasma glucagon: Patterns in patients in chronic renal failure and diabetes. J Clin Endocrinol Metab 42: 173-176

19. Valverde I, Villaneuva ML, Lozano I, Marco J (1974) Presence of glucagon immunoreactivity in the globulin fraction of human plasma ("Big plasma glucagon"). J Clin Endocrinol Metab 39: 1090-1098

20. Weir GC, Turner RC, Martin D B (1973) Glucagon radioimmunoassay using antiserum $30 \mathrm{~K}$ : Interference by plasma. Horm Metab Res 5: 241-244

21. Barros d'Sa, Buchanan KD (1977) Role of gastrointestinal hormones in the response to massive resection of the small bowel. Gut 18: 877-881

22. Bloom SR (1972) An enteroglucagon tumour. Gut 13: $520-523$

23. Krug E (1978) Antilipolytic nature of gut GLI and mode of action of two highly potent intestinal lipolytic species in birds. Horm Metab Res 10: 505-509

24. Rehfeld J, Heding L (1970) Increased release of gut glucagon in reactive hypoglycaemia. Br Med J II: 706-707

25. Marco J, Faloona GR, Unger R H (1971) Effect of endogenous intestinal glucagon-like immunoreactivity (GLI) on insulin secretion and glucose concentrations in dogs. J Clin Endocrinol Metab 33: 318-325

26. Moody A J, Jacobsen H, Sundby F (1977) Gastric glucagon and gut glucagon-like immunoreactants In: Bloom SR (ed) Gut hormones. Churchill Livingston, Edinburgh, p 369-378

27. Barnes AJ, Bloom SR (1976) Pancreatectomized man: a model for diabetes without glucagon. Lancet I: $218-221$

28. Holst J J (1978) Extrapancreatic glucagons. Digestion 17: 168-190

29. Sundby F, Jacobsen H, Moody A J (1976) Purification and characterisation of a protein from porcine gut with glucagonlike immunoreactivity. Horm Metab Res 8: 366-371

30. Jacobsen H, Demandt A, Moody A J, Sundby F (1977) Sequence analysis of porcine gut GLI. Biochim Biophys Acta 493: 452-459

31. Tager HS, Steiner DF (1973) Isolation of a glucagon containing peptide: primary structure of a possible fragment of proglucagon. Proc Natl Acad Sci USA 70: 2321-2324

32. Ravazzola M, Siperstein A, Moody AJ, Sundby F, Jacobsen H, Orci L (1979) Glicentin immunoreactive cells: their relationship to glucagon-producing cells, Endocrinology 105: 499-508

33. Ravazzola M, Siperstein A, Moody AJ, Sundby F, Jacobsen H, Orci L (1979) Glicentin: a precursor of glucagon? Life Sci 25: $287-290$

34. Patzelt C, Tager HS, Carrol RJ, Steiner DF (1979) Identification and processing of proglucagon in pancreatic islets. Nature $282,260-266$

35. Mains RE, Eipper B A, Ling N (1977) Common precursor to corticotropins and endorphins. Proc Natl Acad Sci USA 74: 3014-3018

Dr. J. M. Conlon

Department of Clinical Biochemistry

Royal Victoria Infirmary

Newcastle upon Tyne NE1 4LP

England

Editor's Note. For the time being we would request all would-be authors who intend to write about glucagon to adopt the terminology suggested by Dr. Conlon in the above editorial. Apart from aiding in the general demystification process, this will also lead to your having a less confused Editor in Chief. 